\title{
“THERE'S A LOT OF CANCER HERE...” ENVIRONMENTAL RISK PERCEPTION AND MORTALITY AMONG WOMEN WHO LIVE IN AN INDUSTRIAL CORRIDOR IN MEXICO. A SEQUENTIAL MIXED STUDY
}

\author{
Minerva CATALÁN-VÁZQUEZ ${ }^{1}$, Horacio RIOJAS-RODRÍGUEZ ${ }^{2 *}$, \\ Blanca Estela PELCASTRE-VILLAFUERTE ${ }^{3}$, Luz Angélica DE LA SIERRA-DE LA VEGA ${ }^{2}$ \\ and Mary Carmen BALTAZAR-REYES ${ }^{2}$
}

\footnotetext{
${ }^{1}$ Departamento de Investigación en Epidemiología Clínica, Instituto Nacional de Enfermedades Respiratorias Ismael Cosío Villegas, Calzada de Tlalpan 4502, Colonia Sección XVI, 14080 Ciudad de México, México

${ }^{2}$ Dirección de Salud Ambiental, Centro de Investigaciones en Salud Poblacional, Instituto Nacional de Salud Pública, Av. Universidad 655, Col. Santa Ma. Ahuacatitlán, 62100 Cuernavaca, Morelos, México

${ }^{3}$ Dirección de Determinantes y Retos de los Sistemas de Salud, Centro de Investigación en Sistemas de Salud, Instituto Nacional de Salud Pública, Av. Universidad 655, Col. Santa Ma. Ahuacatitlán, 62100 Cuernavaca, Morelos, México

*Autor para correspondencia: hriojas@insp.mx
}

(Received May 2017; accepted February 2018)

Key words: industrial pollution, risk, public awareness, mixed design

\begin{abstract}
The objectives of this study were to characterize the environmental risks attributed to the Quetzalcóatl industrial corridor and to compare the records as opposed to the perceptions of increased mortality among community residents. A sequential mixed method design was used. Women in the community closest to the industrial corridor reported more respiratory disorders and more cases of cancer. They also referred to having been fearful during pregnancy because of a history in the community of premature births. From 2005 to 2007, the mortality rate for working-age women with cancer in the community closest to the corridor was significantly higher than the national rate $(p<0.05)$. An increase in the number of newborn deaths was observed in 1998 and 2000, with rate ratios of 5.8 (CI 3.1-6.9) and 2.9 (CI, 1.2-4.2), respectively. The integrated analysis of the qualitative and quantitative information enabled us to identify a correspondence between social perception of risk from industrial pollution and mortality registered in the study area. The experience of foul odors, the observation of increased cases of cancer and socio-cultural factors contribute to a perceived increased risk by women in the community closer to the industrial corridor. These results have implications for environmental policies in the industrial corridor, particularly with regard to risk mitigation and communication.
\end{abstract}

Palabras clave: contaminación industrial, riesgo, conciencia pública, diseño mixto

\section{RESUMEN}

Los objetivos de este estudio fueron caracterizar los riesgos ambientales atribuidos al corredor industrial Quetzalcóatl y comparar los registros de mortalidad con las percepciones de los residentes de las comunidades. Se utilizó un diseño de método mixto secuencial. Las mujeres de la comunidad más cercana al corredor industrial reportaron más padecimientos respiratorios y más casos de cáncer. También refirieron 
haber tenido temor durante el embarazo debido a la historia de partos prematuros que hay en la comunidad. De 2005 a 2007, en la comunidad más cercana al corredor industrial, la tasa de mortalidad de mujeres en edad laboral con cáncer fue significativamente más alta que la tasa nacional $(\mathrm{p}<0.05)$. Se observó un aumento en el número de muertes de recién nacidos en 1998 y 2000, con razón de tasas de 5.8 (IC 3.1-6.9) y 2.9 (IC, 1.2-4.2), respectivamente. El análisis integrado de la información cualitativa y cuantitativa permitió identificar una correspondencia entre la percepción social del riesgo por contaminación industrial y la mortalidad registrada en el área de estudio. La experiencia de malos olores, la observación del aumento de los casos de cáncer y los factores socioculturales contribuyeron a que las mujeres de la comunidad más cercana al corredor industrial percibieran un riesgo más alto. Estos resultados tienen implicaciones para las políticas ambientales en el corredor industrial, particularmente respecto a la mitigación y comunicación de riesgos.

\section{INTRODUCTION}

Development of industrial complexes has caused substantial damage to the environment and to human health (Janmaimool and Watanabe 2014). Several studies have demonstrated that dwellers of residential areas bordered by industrial installations report foul odors, are at greater risk for symptoms such as wheezing and upper respiratory disorders (Tanyanont and Vichit-Vadakan 2012) and exhibit higher levels of heavy metals such as cadmium, than their control group counterparts (Interdonato et al. 2014).

Other studies have indicated that exposed communities are at greater risk for death from cancer (Bulka et al. 2013, García-Pérez et al. 2015, FernándezNavarro et al. 2017), and display increased anxiety and psychological stress with a wide range of effects on their health and wellbeing (Cutchin et al. 2008).

The Quetzalcóatl industrial corridor in the state of Puebla is a vivid example of these conditions. This industrial corridor has 16 different industries, including textiles, metallurgy, automotive, medical pharmaceutical products and food dehydration. One of these companies incinerates biological-infectious wastes (BIW). These industries also coexist with agricultural activities that use insecticides and chemical fertilizers.

All of these economic activities have caused serious environmental pollution in the region, which has created a complex situation related to chemical exposure in the communities (Montero 2004). In addition, it is important to note that this environmental deterioration is part of a much broader and complex problem in the Atoyac River basin, one of the largest basins in the state of Puebla. It has resulted from the establishment in the region of the maquila textile factories as well as three large industrial complexes - the Independence Petrochemical
Complex belonging to Petróleos Mexicanos (built in 1968) and the Quetzalcóatl and Huejotzingo corridors-(Morales et al. 2005).

Recent studies indicate that water from the river poses a public health risk involving toxicological and mutagenic parameters (Montero et al. 2006, Sandoval et al. 2009). The population potentially exposed to pollutants in the Atoyac River sub-basin is estimated to be 2005444 inhabitants-1 875808 in Puebla and 124508 in Tlaxcala (neighboring state) (Montero et al. 2006).

One approach to understanding environmental risk is to analyze the perceptions of community members. Factoring people's perceptions into risk analysis can contribute to identifying effective mitigation measures (Ramos-Ribeiro 2014). It has been documented that lack of knowledge on how communities perceive risk hinders the implementation of potentially successful educational, communication and public policy strategies. Disregarding local perceptions often results in interventional contents that do not address the wide variety of social views and necessities attached to environmental problems (Ávila 2015).

To characterize the environmental risks attributed to the Quetzalcóatl industrial corridor and the social response to perceived pollution, as well as to compare records of increased mortality of inhabitants with the social perception of deaths in the localities, a sequential mixed method study was conducted in two communities which used to be entirely rural but are now located in an industrial zone.

The two communities are located at different distances from the Quetzalcóatl industrial corridor in the municipality of Huejotzingo, state of Puebla, Mexico. One is the Santa Ana Xalmimilulco community, which is $1 \mathrm{~km}$ from the corridor and the other is Huejotzingo, which is further away $(7 \mathrm{~km})($ Fig. 1). 


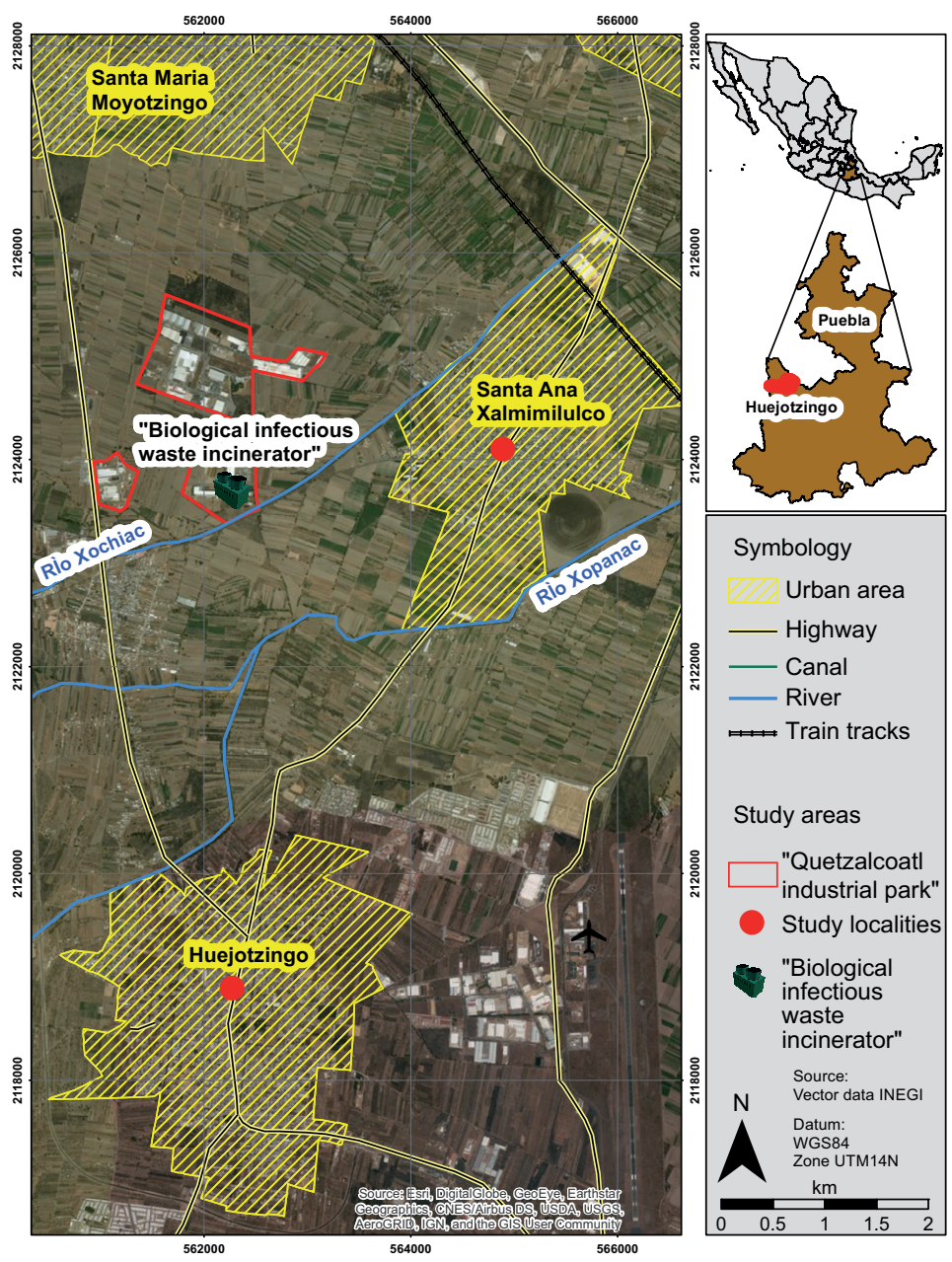

Fig. 1. Study localities

The study was designed based on the concern expressed by the inhabitants about the health effects from industrial pollution and their perception of an increase in cancer cases in the communities.

The residents of Santa Ana Xalmimilulco have been protesting since 2006 because of the foul odors and health effects which they associate with the pollution from the BIW incinerator, particularly an increase in cancer cases among women in the community. In May 2007 the residents of Santa Ana Xalmimilulco continued their protests to demand the definitive shutdown of the company by closing schools and attempting to block the Mexico-Puebla highway. The protest was repressed by public authorities (Mota 2007).

As a result of these social protests, the Procuraduría Federal de Protección al Ambiente (the Mexican environmental protection agency) temporarily closed the incinerator until the company installed a continuous monitoring system and a gas cleaning system to decrease the foul odors (personal communication, former public official, Santa Ana Xalmimilulco).

To analyze the social concern about the health effects of industrial pollution in the study area, our investigation raised three questions: What are the perceived risks of the women residing in the polluted industrial zone? What mortality trends can be observed among newborns and people with cancer in the area? Is there any association between social perceptions and the mortality data registered?

\section{CONCEPTUAL FRAMEWORK}

Risk perception refers not only to the processing of physical signals and/or information regarding potentially harmful events and activities; it also involves the formation of judgments regarding the 
severity, probability of harm and acceptance of those events and activities (Renn 2008). Thus far, two broad approaches - one psychological, the other sociocultural - have been adopted to study how risks are perceived (Pidgeon 1998).

The psychological method explores the manner in which individuals process and select information about risks; the mental and heuristic strategies they use to make sense of the world (common sense); the semantic images they elaborate regarding risks, and psychometric assessment. The latter, known as the psychometric paradigm, is the one most commonly applied in this field of study (Renn 2008).

Under the psychometric paradigm, risk perception is an individual and inherently subjective psychological process. Also considered quantifiable and predictable, however, psychometric techniques are regarded as the best means of identifying similarities and differences in people's perceptions and attitudes towards risk.

Psychometric studies have shown that the judgments of common people, that is, of those who are not risk experts, include hazard-related properties such as voluntariness, dread, catastrophic consequences, knowledge, familiarity, controllability, prior experience, perceived benefits, equity, and implications for future generations (Slovic 2007).

By contrast, the sociocultural paradigm holds that risk perception and acceptance are rooted in social, institutional and cultural processes. They respond to determinants such as culture, values, influence from the media, socioeconomic status and trust in institutions that regulate and manage risks (Renn 2008). The cultural theory of risk is the most representative model of the sociocultural approach.

According to this theory, risk perception is a collective and cultural construction, not an individual phenomenon (Douglas 1996). Among other exponents of this proposal, Douglas and Wildavsky (1982) argue that people act as parts of social groups; they minimize certain hazards and emphasize others to maintain and control their groups. Consequently, they perceive that which is understood to be polluted and therefore dangerous as a threat to their social order, and to the integrity of both their physical body and the symbolic body of the community or society to which they belong.
Risk perception is thus a multidimensional process that takes place both individually and as part of society. It is influenced by psycho-cognitive and sociocultural factors that vary according to the type of hazard at hand. Specifically with regard to the environment, understanding the differences in the judgments and opinions of risk held by people in industrial communities offers valuable information for designing effective communication and risk management strategies (Janmaimool and Watanabe 2014).

\section{Characteristics of the study communities}

Xalmimilulco has 16125 inhabitants of which $8242(51 \%)$ are women (INEGI 2010). Although it is categorized as a community with medium marginalization $^{1}$ (CONAPO 2010), a significant percentage of the population lives in conditions of poverty and marginalization. For example, of the female population 15 years and older, $56 \%$ has incomplete elementary school and $65 \%$ is illiterate.

The second community, Huejotzingo, is the municipal administrative capital and has 25684 inhabitants, of which $50 \%$ (13337) are women. Huejotzingo is classified as a community with low marginalization (CONAPO 2010). The characteristics of the study communities are presented in Table I.

\section{METHODS}

\section{Design}

We selected these localities for two reasons: Xalmimilulco was located near the Quetzalcóatl industrial corridor and had engaged in social protest against the effects of the neighboring industrial installations; Huejotzingo allowed us to compare the risk perceptions of two communities located at different distances from an industrial corridor. Our study used a sequential mixed design (Creswell and Plano 2011) with a small quantitative component embedded in a predominantly qualitative schema (QUAL-quan) (Bronstein and Kovacs 2013) (Fig. 2).

\section{Qualitative method Procedure}

Forty in-depth interviews were performed with women from the selected communities. Participants

\footnotetext{
${ }^{1}$ Marginalization is associated with lack of social opportunities and limited access to goods and services. Medium-level marginalization refers to the intensity of deprivation. It is estimated based on indicators for education, housing, population distribution and income for work (CONAPO, 2010). http://www.conapo.gob.mx/work/models/CONAPO/Resource/1755/1/images/01Capitulo.pdf).
} 
TABLE I. CHARACTERISTICS OF THE STUDY COMMUNITIES

\begin{tabular}{|c|c|c|}
\hline Socioeconomic indicators & Santa Ana Xalmimilulco & Huejotzingo \\
\hline \multicolumn{3}{|l|}{ Population } \\
\hline Total population* & 16125 & 25684 \\
\hline Female population* & $8242(51.1 \%)$ & $13337(51.9 \%)$ \\
\hline Population 15 years and older & 10812 & 17581 \\
\hline Female Population 15 years and older* & $5628(52.0 \%)$ & $9301(52.9 \%)$ \\
\hline \multicolumn{3}{|l|}{ Education } \\
\hline Female population 15 years and older, illiterate* & $386(65.2 \%)$ & $397(65.9 \%)$ \\
\hline Female population 15 years and older, incomplete elementary school* & $632(55.8 \%)$ & $1098(60.0 \%)$ \\
\hline Average school grade of the female population* & 8.4 & 8.8 \\
\hline \multicolumn{3}{|l|}{ Economy } \\
\hline EAP female population* & $1907(30.6 \%)$ & $3529(33.9 \%)$ \\
\hline Working female population $*$ & $1870(30.8 \%)$ & $3427(34.2 \%)$ \\
\hline \multicolumn{3}{|l|}{ Health services } \\
\hline Population not enrolled in health service networks* & 8128 & 14073 \\
\hline \multicolumn{3}{|l|}{ Housing } \\
\hline$\%$ Private homes without plumbed water** & 11.18 & 10.32 \\
\hline$\%$ private homes without a refrigerator** & 36.4 & 33.1 \\
\hline Degree of marginalization**a & Medium & Low \\
\hline
\end{tabular}

*X Population and Housing Census (INEGI 2010); **National Population Council (CONAPO 2010)

${ }^{a}$ The degree of marginalization is an indicator created by the National Population Council, based on a series of social and economic variables (public services, income, among others) at local and municipality level

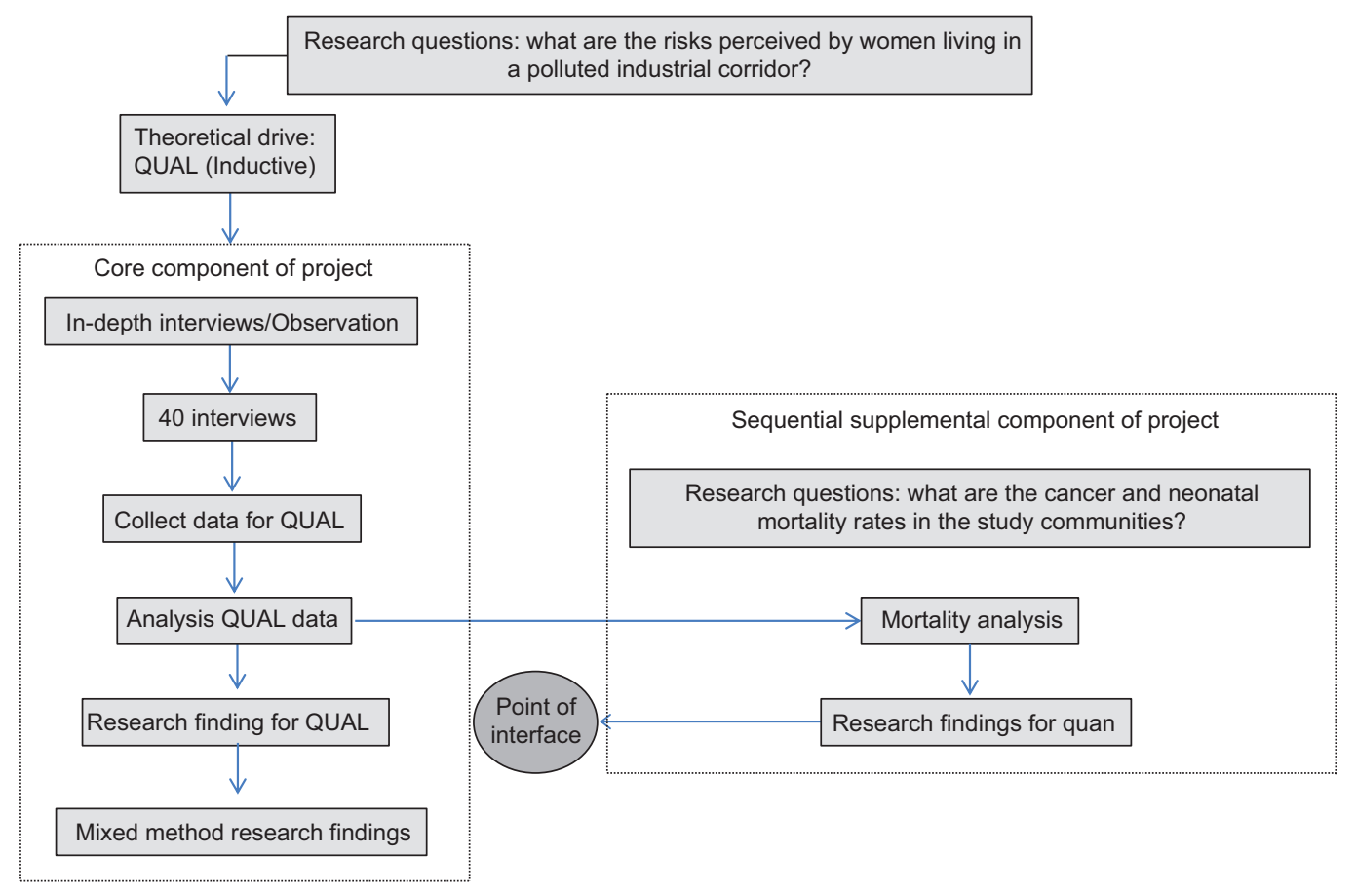

Fig 2. QUAL-quan mixed method design. Adapted from Morse and Niehaus (2009) 
were selected through snowball sampling, with the number of interviews determined based on theoretical saturation. The interviews were performed from October 2009 to June 2010 in the homes of the participants, and followed an interview guide previously designed, which included the following topics: (a) perceived environmental problems, (b) health risks, (c) public response to environmental pollution and (d) social confidence in risk management. Interviews were audio-recorded prior informed verbal consent from the interviewees, and were later transcribed using a word processor.

\section{Participants}

Of the 40 women participating in the study, 22 were from Xalmimilulco and 18 from Huejotzingo. Most were aged 20 to 30 years, had attended middle or high school and had given birth to two or three children. Four participants from Xalmimilulco reported miscarriages. Table II illustrates the socioeconomic and health conditions of the study population.

\section{Analysis}

Data were analyzed using the method proposed by Taylor and Bogdan (1987), which consisted of the following stages: (1) complete and repeated readings of the transcripts to identify the topics contained in the interview guide, (2) search for emerging topics, (3) development of categories based on those topics, (4) coding of data, (5) separation of the data pertaining to each of the categories and (6) interpretation of the data.

This article is based on our analysis of three general topics: (a) perceived environmental problems in the community, (b) connections between pollution and health-illness-death, and (c) the social response to perceived industrial pollution. Coding was performed using the Atlas-ti (v. 5.0) program.

TABLE II. WOMEN PARTICIPATING IN INTERVIEWS

\begin{tabular}{|c|c|c|}
\hline Socioeconomic characteristics & $\begin{array}{l}\text { Santa Ana Xalmimilulco } \\
\qquad(\mathrm{n}=22)\end{array}$ & $\begin{array}{l}\text { Huejotzingo } \\
\qquad(\mathrm{n}=18)\end{array}$ \\
\hline Community of origin & 15 & 15 \\
\hline \multicolumn{3}{|l|}{ Age } \\
\hline$<20$ years & 1 & 0 \\
\hline 20-30 years & 20 & 14 \\
\hline$>30$ years & 1 & 4 \\
\hline \multicolumn{3}{|l|}{ Schooling } \\
\hline Do not know how to read or write & 2 & 0 \\
\hline Elementary/middle school & 13 & 9 \\
\hline High school & 6 & 8 \\
\hline Bachelors' degree & 1 & 1 \\
\hline \multicolumn{3}{|l|}{ Marital status } \\
\hline Single & 2 & 4 \\
\hline Married & 4 & 5 \\
\hline Common law marriage & 16 & 9 \\
\hline Women who have had miscarriages & 4 & 0 \\
\hline \multicolumn{3}{|l|}{ Occupation } \\
\hline Home & 16 & 14 \\
\hline Home and other & 6 & 4 \\
\hline \multicolumn{3}{|l|}{ Religion } \\
\hline Catholic & 20 & 18 \\
\hline Others & 2 & 0 \\
\hline \multicolumn{3}{|l|}{ Type of family } \\
\hline Nuclear & 6 & 3 \\
\hline Extended & 16 & 15 \\
\hline $\begin{array}{l}\text { With illness at the time of the } \\
\text { interview }\end{array}$ & 2 & 3 \\
\hline $\begin{array}{l}\text { Belonging to social networks } \\
\text { (Catholic church) }\end{array}$ & 12 & 1 \\
\hline Partner works in the maquila factory & 12 & 0 \\
\hline $\begin{array}{l}\text { Partner works in the industrial } \\
\text { corridor }\end{array}$ & 0 & 2 \\
\hline
\end{tabular}




\section{Quantitative method Procedure}

Information on causes of mortality was obtained from two secondary sources: (a) 1699 death certificates registered in Xalmimilulco from 1984 to 2010, and (b) 21 general mortality databases from 1990 to 2010 provided by the Instituto Nacional de Estadística y Geografía (National Institute of Statistics and Geography, INEGI) and the Sistema Nacional de Información en Salud (National Health Information System, SINAIS). The information was analyzed using Stata 12.

\section{Mortality of people with cancer}

Information on cancer mortality in the study localities was obtained from death certificates. As many as 10 causes of death were registered for each observation: the "primary cause" referred to the direct source of death; the remaining nine causes included illnesses related to the primary cause. A dichotomous variable was created where "cancer" referred to the presence of any form of cancer (codes ICD-10 or $\mathrm{C} 00-\mathrm{C} 97)$ present at the time of passing and registered as one of the 10 causes of death.

\section{Analysis}

Prevalence of cancer as a cause of death was descriptively analyzed by age group, sex and year according to the information on the community death certificates. Age groups were determined as proposed by the Secretaría de Salud (Mexican ministry of health): 0 to 14 years, $15-64$ years and 65 years and older (SSA 2015). Cancer mortality rates were stratified by sex and age group. The denominators were derived from population projections issued by the Consejo Nacional de Población (National Population Council, CONAPO) for each year considered in the study (CONAPO 2015).

\section{Neonatal deaths \\ Procedure}

Death certificates were the source of information used to calculate the cases of neonatal deaths in the study localities. Neonatal deaths included registered stillbirths and premature newborns. Based on the World Bank definition, we included all deaths occurring within the first 28 days of life (WB 2015).

\section{Analysis of neonatal deaths}

A descriptive analysis of all neonatal deaths in the study localities was conducted. Neonatal mortality rates (the denominator) were determined based on the projection of births issued by the CONAPO for each year analyzed (CONAPO 2015). Then, a linear regression was performed to calculate temporal trends for absolute cases as well as for cancer and neonatal mortality rates. The correlation coefficient (R) was obtained to determine the correlation of trends estimated for the study period. Cancer and neonatal death rates were compared to the national rates reported for each year.

\section{Method integration}

We used a data connection method as our primary design, consisting of an initial qualitative phase followed by a quantitative component to analyze mortality. The interface (integration point) between the two approaches occurred at two points in time. First, when the results of the qualitative phase were obtained. This information allowed us to plan with optimum precision the research questions, data sources and time frame of the quantitative phase of our study. The second interface occurred when we compared the findings of the qualitative analysis - that is, the perception of increased cancer cases - with those of the quantitative analysis concerning registered mortality data.

\section{RESULTS}

\section{Qualitative results}

\section{Perceived environmental problems}

Environmental deterioration in the area

In Xalmimilulco, the women remembered how the environment was in their community when they were children and how it changed as the industries in the corridor slowly became established

In the beginning, there was a lot of clean water, really clean water, many trees... there weren't as many factories as now... now it is full of factories (Xalmimilulco, participant, 31 years old).

The women believed that although the industrial activity in both the community and the corridor was a source of jobs, it also brought about negative consequences in terms of pollution, safety and more risks in general. This was indicated by the following testimony from one of the study participants:

On the one hand... there is more work, but on the other hand it does affect everything, more pollution in the water, there are more risks... especially pollution and safety (Xalmimilulco, participant, 31 years old). 
All the women felt that they were surrounded by pollution, moreover, that their entire environment was polluted, and expressed a feeling of involuntary exposure to this situation with no possibility of changing the environmental conditions or avoiding their effects.

\section{Current environmental problems}

The women in Xalmimilulco indicated that they were currently experiencing pollution in their locality. Table III lists the environmental problems identified by respondents: pollution from the BIW incinerator, from denim laundries, from garbage in public roads, from insufficient public services (such as paved roads and drainage) and from harmful fauna.

The problem they considered to be most important was pollution from the incinerator plant because of the foul odors perceived. They mentioned that the plant burns all types of hospital waste, including human remains, which generates foul and penetrating odors that spread throughout the community.

They burn everything, placentas, organs that are no longer of any use, even bodies... sometimes, even the remains of dogs when they are run over, that is, they burn anything. Yes,
I think that is also why everything is polluted and everything mixes with the smell of human organs and also dog organs, from animals (Xalmimilulco, participant, 23 years old).

Another problem that the women identified as important was pollution generated by the laundries and shops involved in manufacturing denim pants. The chemical substances used in the fading process were sodium permanganate, sodium hyposulphites, potassium and hydrochloric acid. Sources of fuel for the boilers were sewing wastes (scraps of fabric [trash], spools of thread, plastic bottles and bags and styrofoam), burned oils, tar, heavy oil and wood, which according to the women generated a lot of smoke from the stacks belonging to these industries:

...I went and they said - do you know how to apply potassium? Because potassium is applied here. And I said yes, and [they said] if you want come on Monday. And I said okay. And yes, it is very strong when it is applied (Xalmimilulco, participant, 22 years old).

The women indicated that wastewater from the laundries was discharged into the river that runs

TABLE III. PERCEIVED ENVIRONMENTAL PROBLEMS IN THE COMMUNITIES

\begin{tabular}{lcc}
\hline Environmental problems & $\begin{array}{c}\text { Santa Ana Xalmimilulco } \\
(\mathrm{n}=22)\end{array}$ & $\begin{array}{c}\text { Huejotzingo } \\
(\mathrm{n}=18)\end{array}$ \\
\hline $\begin{array}{l}\text { Pollution from the BIW* incinerator: foul and penetrating odors, } \\
\text { smoke and wastewater discharge into the Xochiac River }\end{array}$ & 1 & 1 \\
\hline $\begin{array}{l}\text { Pollution from other industries in the industrial corridor: odors and } \\
\text { wastewater discharge into the Xochiac River }\end{array}$ & 3 \\
$\begin{array}{l}\text { Pollution from denim laundries: smoke, wastewater discharge and } \\
\text { municipal drainage into the Xochiac River and exposure to chemicals }\end{array}$ & 3 \\
\hline $\begin{array}{l}\text { Pollution from garbage in public roads, empty lots, ravines and/or } \\
\text { burning of garbage: foul and penetrating odors }\end{array}$ & 3 \\
\hline $\begin{array}{l}\text { Pollution from the sanitary landfill: foul and penetrating odors } \\
\begin{array}{l}\text { Lack of public services: dusty roads and poor functioning of municipal } \\
\text { drainage }\end{array}\end{array}$ & 3 \\
\hline $\begin{array}{l}\text { Pollution created by cattle, pigs and/or horses in the community and } \\
\text { by defecation outdoors: harmful fauna, bad odors }\end{array}$ & 3 \\
\hline
\end{tabular}

$\mathrm{n}$ : number of interviews conducted in each community; 1 : the topic was mentioned in one interview; 2: the topic was mentioned in two interviews; 3 : the topic was mentioned in three or more interviews BIW: biological-infectious wastes 
through the community or into the public drainage system, generating more pollution. In some cases, wastewater was used to irrigate vegetable crops, which also presents a health risk.

Additional problems that existed included a lack of public services such as paved roads, creating a large amount of dust from the streets, and poorly functioning drains which causes household sewage to back up into the streets.

Problems resulting from the disposal and inadequate handling of garbage are also considered to be important. And finally, there is the problem of harmful fauna-street dogs and flies-associated with the presence of clandestine slaughterhouses, butchers and dairies in the community.

Unlike the women from Xalmimilulco, those from Huejotzingo considered the main environmental problem to be garbage that was thrown into public streets and empty lots and dumped in the sanitary landfill located $1 \mathrm{~km}$ from the community. The pollution associated with factories in or surrounding the community was considered to be a lesser problem. Furthermore, the women report that they enjoy living in their community because there is not a lot of pollution, it is a quiet place and many customs and traditions are still preserved.

They believed that the problem of pollution occurred where there were more industrial activities, more factories, and where there were foul odors, such as in Xalmimilulco.

\section{Industrial pollution and its relationship with the health-illness-death process}

When the women from Xalmimilulco were asked about the impact of pollution on health, they said that all the pollution combined could affect their health. However, they considered the BIW incinerator and the denim laundries, which they also called factories, to be the most dangerous sources of pollution.

Above all, pollution comes from the Ecotérmica [incinerator]. Then, a very bad smell arises and you can't stand it and it's getting really bad. That is going to harm us, isn't it? (Xalmimilulco, participant, 22 years old).

The women attributed several health impacts to the pollution they experienced daily. Most mentioned that air pollution (odors) from the BIW incinerator caused respiratory problems such as the flu, coughs and dry noses (Table IV). In addition, they reported that the pollution they experienced daily had caused more illnesses in the community, and that one of the illnesses which had increased was cancer, especially among young women.

The women interviewed repeatedly referred to this illness and mentioned that they knew cases of women with cancer.

It causes cancer, especially in women, or rather everyone; I think in everyone because

TABLE IV. IMPACT OF INDUSTRIAL POLLUTION ON THE HEALTH-ILLNESS-DEATH PROCESS

\begin{tabular}{lcc}
\hline Impacts on health & $\begin{array}{c}\text { Santa Ana Xalmimilulco } \\
(\mathrm{n}=22)\end{array}$ & $\begin{array}{c}\text { Huejotzingo } \\
(\mathrm{n}=18)\end{array}$ \\
\hline Respiratory (cough, flu, burning throat, headache) & 3 & 1 \\
Congenital deformity & 3 & 1 \\
Cancer & 3 & 1 \\
Know people with cancer or have died from cancer & 3 & 0 \\
Fear and uncertainty during pregnancy & 3 & 0 \\
Uncertainty about long-term effects, especially in children & 3 & 0 \\
Premature births & 2 & 0 \\
More risk of becoming ill & 3 & 0 \\
Children, most vulnerable to pollution & 3 & 0 \\
Skin (rashes, itching) & 3 & 0 \\
Affects the whole body & 2 & 0 \\
Increases severity of illnesses & 1 & 3 \\
Disabilities in children & 2 & 0 \\
Gastrointestinal effects & 2 & 0 \\
Unknown illnesses & 3 & 0 \\
\hline
\end{tabular}

$\mathrm{n}$ : number of interviews conducted in each community; 1: the topic was mentioned in one interview; 2: the topic was mentioned in two interviews; 3 : the topic was mentioned in three or more interviews 
we breathe the air... I know a woman who lives close to San Mateo... even this person's mother died of breast cancer. So, I can say, another woman I know from here, well there is a lot around here, [a lot] of cancer (Xalmimilulco, participant, 31 years old).

Also, some of the women interviewed mentioned they were fearful and uncertain during their pregnancies because they knew about cases of women who had given birth to babies with congenital malformations or suffered premature births.

There are even times when the babies have six fingers on one hand or one hand is larger or smaller, so there are always cases, so you live with that fear. That is, you say, "Please God don't let that happen to me" because, well, it would be awful... yes, during all my pregnancy I was like that (Xalmimilulco, participant, 28 years).

The uncertainty related with pollution in terms of harming their children's health or their own health continued even after their children were born, which is reflected in how women responded to the question about whether they or their children currently had any illnesses that they considered to be related with pollution. Their answer was: "not right now, no" or "no, not yet, as of now", or "not now, at least."

The women disclosed that, since there are many children with disabilities, a school for children with special needs was opened to take care of these cases in Xalmimilulco and the neighboring communities.

By contrast, women in Huejotzingo did not attribute health problems to industrial pollution but rather to garbage. Health effects attributed to garbage included respiratory problems, flu, coughs, fever and headaches. With respect to health risks caused by the BIW incinerator, the women were unaware of the existence of this facility. Those who knew about it did not believe the pollution emitted by this plant affected them, because it was not in their community.

Although they used firewood and coal to cook, women in Huejotzingo believed that smoke did not represent a health risk, since it was white and did not smell; therefore it was pure, unlike the smoke from industries, which was black, smelled bad and therefore produced pollution and illness. They also believed that, since pollution did not occur often in their community, it did not significantly affect their health, and that there were no illnesses related to environmental pollution because they lived far from the industrial corridor.

\section{Social response}

The main strategy adopted by women from Xalmimilulco to decrease exposure to the pollution they experienced was to spend more time inside. They limited their children's outdoor activities. They also closed their homes' doors and windows when odors were strong (Table V). Some women mention being careful with their children's diets, giving them more fruits and vegetables and using medicine to prevent respiratory problems. They comment that the adults just cover their mouths with a cloth or a scarf or use a face mask when odors are strongest.

At the collective level, women signed complaints demanding authorities to address the environmental problems caused by the incinerator. Some also participated in the social protests in May 2007 in which the community joined together to demand the state government's intervention to shut down the incinerator.

The women's participation in this last social response was minimal because of pregnancy or having small children and the fear that they would get hurt. They have not organized to actively participate in attracting more attention to their environmental problems because they believe they will be ignored by authorities, and also because they are still subject to their husbands' decision about letting them participate in environmental problems.

When women in Xalmimilulco were asked whether they liked living in their community, the majority responded affirmatively despite the pollution; their families resided there and they had acquaintances with whom they shared values, traditions and customs. But primarily, they liked it because there was a lot of work at the pants factory (maquila).

Unlike the women from Xalmimilulco, in Huejotzingo only women living closest to the sanitary landfill mentioned limiting their children's time outdoors and closing their homes' doors and windows. Other women considered Huejotzingo to be a place with little pollution, which was beneficial to the normal development of the children.

\section{Quantitative results Mortality analysis}

The descriptive analysis of deaths from cancer in the two study localities showed that the greatest annual incidence in Santa Ana Xalmimilulco occurred during 1997, 2005 and 2007, with 11 cases per year, and the lowest incidence was in 1985 and 1993, with two cases. In Huejotzingo, the highest incidence of deaths from cancer occurred in 2000 with five cases among men and 10 among women (there was no 
TABLE V. PUBLIC RESPONSE TO ENVIRONMENTAL POLLUTION

\begin{tabular}{lcc}
\hline Types of responses & $\begin{array}{c}\text { Santa Ana Xalmimilulco } \\
(\mathrm{n}=22)\end{array}$ & $\begin{array}{c}\text { Huejotzingo } \\
(\mathrm{n}=18)\end{array}$ \\
\hline $\begin{array}{l}\text { On the individual level } \\
\text { Keep children inside the house until the bad odors associated } \\
\text { with the incinerator are gone }\end{array}$ & 3 & 0 \\
$\begin{array}{l}\text { In general, try to have the children spend more time indoors } \\
\text { than outdoors }\end{array}$ & 3 & 1 \\
Use face mask when bad odors reach the community & 3 & 2 \\
Close windows and doors & 3 & 0 \\
Limit physical activities of the children, such as exercising & 2 & 0 \\
Disinfect foods, floors and clothes & 1 & 0 \\
Boil water & 1 & 0 \\
Take vitamins & & 0 \\
\hline At the collective level & 1 & 0 \\
Signing petitions to close the BIW plant & 3 & 2 \\
Participation in the social movement to demand the closing of & & 0 \\
Incinerator & 3 & 2 \\
Participation in NGO to demand the closing of the sanitary & 0 & 0
\end{tabular}

$\mathrm{n}$ : number of interviews conducted in each community; 1: the topic was mentioned in one interview; 2: the topic was mentioned in two interviews; 3 : the topic was mentioned in three or more interviews BIW: biological-infectious wastes

statistically significant difference). The correlation coefficient for trends was not statistically significant in Santa Ana Xalmimilulco or Huejotzingo.

Our analysis by age and sex in Xalmimilulco indicated that between 1984 and 2010 the mortality rate among women in the 15 to 64 year old group who suffered from some form of cancer at the time of death (58 cases) was significantly higher than in men ( 21 cases) (rate ratio $p<0.05)$. In addition, the mortality rate among women with cancer in this age group from 2005 to 2009 was significantly higher than the national rate, with the rate ratio reaching 12.5 (CI 6.34-18.24).

\section{Neonatal deaths}

While no temporal trends were found in neonatal deaths in Xalmimilulco, an increase occurred during two years: in 1998, when the neonatal mortality rate was 39.7 per 1000 births, and in 2000, when it was 23.7. Based on national neonatal mortality rates, the rates ratio stood at 3.5 (CI 3.2-3.8) in 1998 and 2.4 (CI 2.2-2.6) in 2000. In Huejotzingo, the neonatal mortality rate ratio was significant during two years: in 2002 and 2003, with 5.6 (CI 5.2-5.9) and 4.2 (CI 3.9-5.5) per 1000 births, respectively (Table VI).

\section{Method integration}

An integrated analysis of the qualitative and quantitative data collected revealed a correspondence between the social perception of risk from industrial pollution (perception of an increase in cancer cases) and the mortality records in the study area during specific periods.

\section{DISCUSSION}

What were the risks perceived by women in the polluted industrial zone? According to our qualitative findings, women in Xalmimilulco perceived that industrial activity had caused substantial environmental pollution and serious damage to their health. The environmental problems they identified were ranked by visual and olfactory perception. With respect to health risks, participants were most concerned about the growing incidence of respiratory disorders, cancer cases, and problems during pregnancy.

The women from Xalmimilulco were aware that industrial development provided more work for locals and migrants, but also involuntarily exposed them and their families to environmental pollutants and health risks. They were reminded daily of these risks by the foul odors from the incinerator. These results match those of a study conducted by Luria et al. (2009) in northeast England. According to these authors, unfamiliar odors can trigger intense risk perception because of their association with asthma and cancer. The mere presence of a foul odor can give 


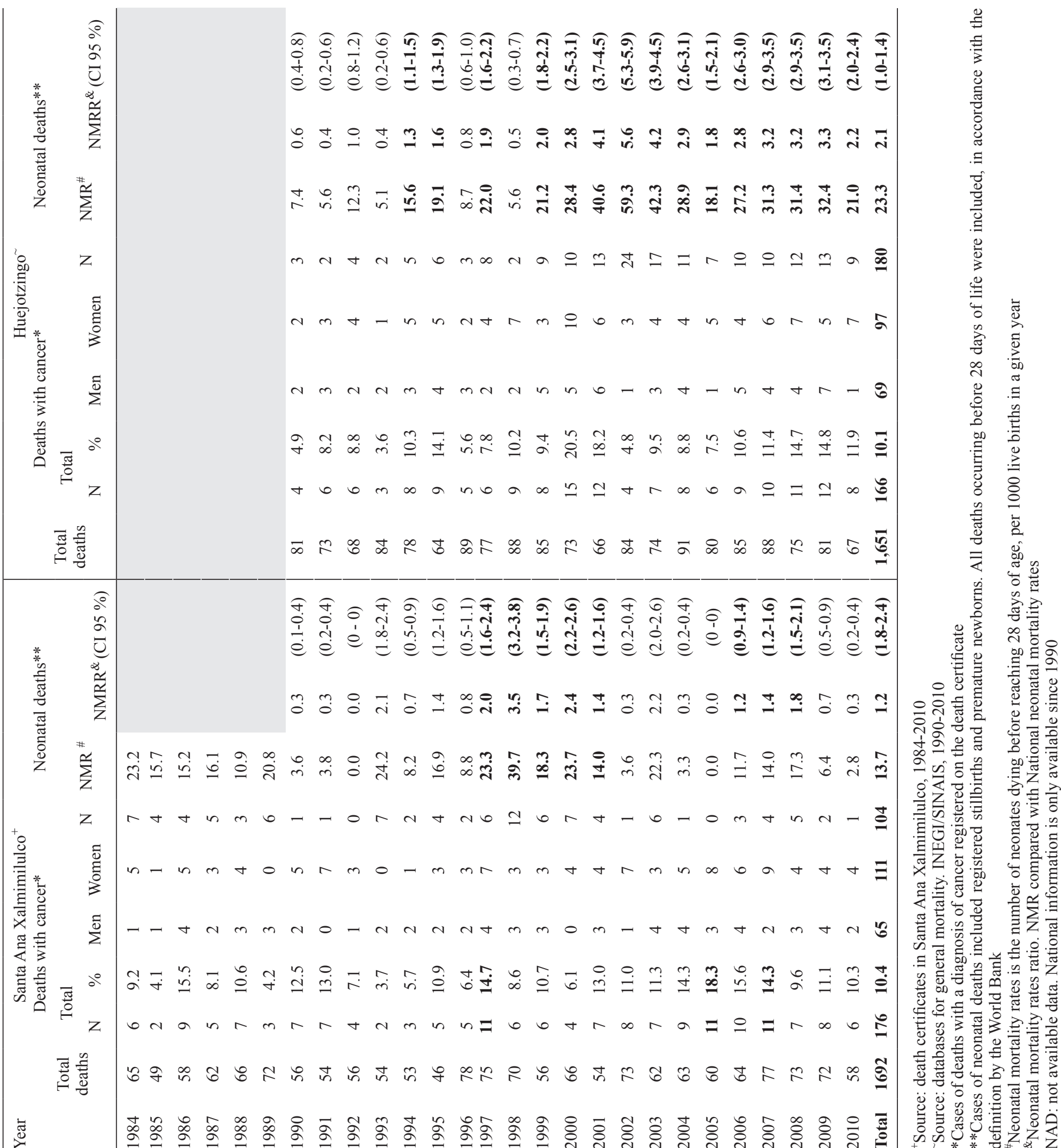


rise to adverse sensory responses and complaints. Additionally, individuals who are hypersensitive to odor-causing chemicals can experience physical and mental distress culminating in risk perception.

Other studies have demonstrated that, even when unrelated to any known danger to human health, environmental odors can affect the psychophysical wellbeing of those exposed (Capelli et al. 2007). The connection of foul odors to health risk perception has also been evidenced by Axelsson et al. (2013) in Sweden, where the opening of a petrochemical facility caused irritation and concern about health risks among the neighboring residents.

Sensory experience renders the proximity of an industrial zone a key variable in how people perceive the air quality and health status of their communities. They regard pollution as a serious health hazard for themselves, their families and their communities (Guo et al. 2016). As reported by Omanga et al. (2014), "health status and distance from a polluting facility have been shown to be a strong predictor of risk perception... Obviously, people who live closest bear the burden of pollution (odor, smoke, dust, etc.) and naturally believe it is affecting their health".

Other studies on risk perception related specifically to waste incinerators indicated that people residing near an incinerator plant exhibited higher levels of stress, anxiety and depression than those residing far from the plant. According to the study, these psychological conditions emerged from the interaction between ailments attributed to incinerator wastes and the perception of risk in the community (Lima 2004).

The quantitative data showed an increase in the deaths of women with cancer in the study area. Integrated analysis of the qualitative and quantitative information demonstrated that the social perception of risk from industrial pollution corresponded to the mortality rates registered in the study area during specific periods.

The perception of risk from industrial pollution is considered to be substantiated by two events that were identified by the quantitative study and by what the women undoubtedly observed in their community: increased deaths of women with cancer during productive ages (15-64) between the years 2005 and 2007, and increased cases of neonatal mortality rates, which surpassed the national rates, in 1998 and 2000.

Our observations regarding differences in the risk perceptions of the Santa Ana Xalmimilulco and Huejotzingo communities, as well as an association between the social perception of risk and local mortality records, are consistent with the findings of Interdonato et al. (2014) in Sicily and with those of Janmaimool and Watanabe (2014) in Thailand. The former relate that, unlike individuals residing in environmentally unexposed areas, those subjected to industrial pollution present a high risk perception. Janmaimool and Watanabe (2014) indicate that residents of high-risk areas (determined by levels of dibenzene, 1,3-butadiene, $\mathrm{SO}_{2}$ and $\mathrm{NO}_{2}$ ) display greater risk perception regarding their psychological and physical health than their low-risk counterparts. These people specify respiratory disorders, discomfort due to pollution, and adverse effects on their everyday lives. The authors conclude that the risk perception of common people, that is, of those who are not risk experts, can reflect the real nature of risks.

In line with the findings of Wachinger et al. (2013), the results of our study support the notion that experiencing pollution on a daily basis is a decisive factor in the formation of risk perception.

Studies on environmental risk and hazard have generally argued that particular hazards are understood within the context of a community as a whole (Day 2007). For example, in a study conducted in an Australian community, Whittaker (1998) found that social concerns regarding the risk of cancer due to the contamination derived from a residual disposal site and from the radioactivity from mining activities incorporated a range of social meanings. The perception of threat among residents pertained not only to the sites themselves, but also to certain characteristics of the community's social space and underlying values related to the country's political culture and economic policy. Additionally, risk perception among community members included a sense of loss and disempowerment regarding the ability to control their own future as a community.

In our case, the women from Xalmimilulco perceived a larger amount of environmental problems than those in Huejotzingo, both in their microenvironment due to pollution from the maquila factories and the lack of public services, as well as in their macro-environment from the large-scale industrial activities surrounding them, including the BIW incinerator.

Since most participants were 20-30-years-old, this group of women represented a generation of peasant girls who became the daughters and wives of the laborers or became workers themselves. They experienced the transformation of agricultural fields into industrialized zones as a result of the industrial development model followed in the region in the 1990s.

The macro-environment changed from a landscape dominated by nature to one controlled by the industries 
that slowly established themselves in the industrial corridor. Meanwhile, the textile industry led to the change in the micro-environment from an entirely rural community to one of a maquila factory community.

Furthermore, industries that began to take over very important local resources - for example water-began to create environmental pollution problems such that this entire industrial transformation resulted in great exposure to various pollutants and large health risks, as documented by previous studies (Montero 2004, Morales et al. 2005).

These changes undoubtedly also impact the perception and representation of risk in the community. As a result, women cannot discuss pollution, environmental risk or public health independently from the social, political, economic and cultural context in which these events evolve and are experienced.

At the time of the study, the social response in the face of environmental contamination was directed to a greater extent toward carrying out actions to mitigate the impacts of exposure. Although this aids in decreasing environmental exposure, it also reduces the children's physical activity, which raises some concern given the prevalence of overweight and obesity at the national level in Mexico, which is $34.4 \%$ for children aged 5-11 years old and $35 \%$ for adolescents between the ages of 12 and 19 years (INSP 2012).

While women allude to a lack of leadership in responding to the environmental problems in the region, they also live with the memory of confrontation and the state government's repression of the community in 2007, when residents attempted to close the Mexico-Puebla highway to protest pollution and the perceived health damages (SERAPAZ 2008).

\section{CONCLUSIONS}

The perception of risk and the social response of communities to perceived risk emanate, on one hand, from the interaction of the psychological and cognitive factors behind the daily-life experiences of people in specific environments, and on the other, from the distinctive characteristics of each community as regards its economic, social and cultural dimensions. This approach enriched our quantitative data with the voices, experiences and perceptions of the people. It allowed us to demonstrate that the social perception of risk from industrial pollution matched the mortality records in the study area during specific periods. We therefore wish to highlight the contributions of mixed designs to integral risk assessment.
The findings of this case study can contribute not only to the formulation of targeted environmental and social policies, but also, and most importantly, to an effective involvement of women in strategies aimed at communicating and managing risks.

The descriptions that women in our study provided of their deteriorated environment and associated health risks as well as the results of our mortality analysis point out the need for conducting studies that broadly characterize the sources of pollution, polluting emissions, health risks and local vulnerability. It is important to focus future lines of research on the relationship between industrial complexes and local epidemiologic profiles.

A more in-depth analysis is required on the environmental and social determinants of the collective health-disease process in the region, specifically with regard to the manner in which cancer is historically and socially produced in these communities. There is evidence that exposure to dioxins and furans causes a high prevalence of genetic damage and a predisposition to cancer (Baltazar et al. 2013).

Because there is no single cancer register in Mexico, we were unable to analyze the incidence of different forms of cancer at the national, regional and local levels. Our study therefore considered only deaths registered under local death certificates, and identified diagnosed cases of cancer at the time of death. We relied on death certificates as the most reliable official source of information on cancer, but they provided information on expired community members only; we did not have the opportunity to identify the incidence of cancer among those still living.

It is imperative to review the public policies for the disposal of hazardous biological-infectious wastes in Mexico that permit BIW incinerators to operate near communities. Accordingly, it is important to strengthen institutional capacities for establishing an environmental monitoring system linked to an epidemiological surveillance system and to an integral communication program on environmental pollution risks in the area. Setting up participative communication mechanisms would not only contribute to restoring social trust, but would also favor effective risk management. Additionally, land use policies must be reformed with a view to enhancing wellbeing and development in communities.

Finally, it is of primary importance to assess the industrial development model that is creating a social system focused on the profits and productivity of large companies without enforcing the rights of communities to health and wellbeing. 
It is noteworthy that accountability mechanisms for environmental issues in Mexico are limited by legal loopholes that prevent populations from protecting themselves against the hazard exposure they often endure. For instance, a diagnosis of the Atoyac River demonstrated that, in Puebla, relationships between enterprises and local and state-level government institutions, as well as between institutions and local residents, were characterized by a lack of transparency and accountability (SDUS 2017).

The two elements that favored our study case were the presence of social mobilization and linkages with the academic community, both of which gave social visibility to the local crisis. Instruments and mechanisms for creating a culture of environmental protection are sorely needed, e.g., external audits, social comptrollers, and provisions for ensuring access to environmental information.

Notwithstanding the above, it should be noted that some progress has been made in the establishment of institutional spaces intended to address social demands for environmental protection. In 2016, the municipality of Puebla established a committee comprised of the three government levels, the business sector and the academic community, with the purpose of conducting a comprehensive diagnosis of the Atoyac River situation. The results served as a basis for the formulation of a master plan to rescue the Atoyac River (SDUS 2017). Although the plan was confined to the municipality of Puebla, it marked a milestone in the management of environmental problems by contemplating transparency and accountability as components of a major strategy.

Finally, this year (2017), the Comisión Nacional de Derechos Humanos (National Commission for Human Rights, CNDH) issued recommendation 10/2017 to the effect that civil servants at all government levels shall be responsible for acts and omissions in the exercise of their functions regarding prevention of pollution. Specific reference is made to the responsibility of the federal, state (Puebla and Tlaxcala) and municipal (Huejotzingo and the other municipalities involved in the public demand) governments. The $\mathrm{CNDH}$ recommendation also establishes that the victims of environmental damage shall be provided reparation by implementing the principles of restitution, rehabilitation, satisfaction and guarantees of non-repetition.

In addition, the recommendation mandates identifying, prosecuting, trying and sanctioning the parties liable for the damage with a view to restoring and promoting the conditions required for the enjoyment and exercise of the human right to a healthy environment, clean water, and accessible information (CNDH 2017).

The fact that the study does not report the perceptions and positions of other social actors can be considered a limitation. Nonetheless, our work offers a twofold contribution to risk analysis: 1) it is the firstever attempt to study environmental risk in Mexico under a methodological approach based on both perception and measurement, and 2) evidence from our integrated analysis of qualitative and quantitative components clearly demonstrates that perception is an accurate indicator for actual and objective risk experienced by environmentally exposed populations.

\section{ACKNOWLEDGMENTS}

The authors would like to thank all the women from Santa Ana Xalmimilulco and Huejotzingo for their time and willingness to participate in the in-depth interviews, as well as the local authorities who made the development of this study possible. The project was approved by the Comité de Ética en Investigación of the Instituto Nacional de Enfermedades Respiratorias, code S03-10 and financed by the Consejo Nacional de Ciencia y Tecnología of Mexico, project number SSA/IMSS/ISSSTE 69901.

\section{REFERENCES}

Ávila B. (2015). Un estudio sobre la percepción del riesgo de poblaciones vulnerables al cambio climático en la cuenca del Papaloapan. Ph.D. thesis. Instituto de Investigaciones en Educación, Universidad Veracruzana, Veracruz, Mexico, 254 pp.

Axelsson G., Stockfelt L., Andersson E., Gidlof-Gunnarsson A., Sallsten G. and Barregard L. (2013). Annoyance and Worry in a petrochemical industrial area-Prevalence, time trends and risk indicators. Int. J. Environ. Res. Pub. He. 10 (4), 1418-1438.

DOI: 10.3390/ijerph10041418

Baltazar-Reyes M.C., Riojas-Rodríguez H., CatalánVázquez M., Ostrosky-Shejet P. and Sordo M. (2013). Daño genotóxico en embarazadas expuestas a dioxinas y furanos y su percepción del riesgo. Memorias. XII Congreso Español de Salud Ambiental-VIII Conferencia Nacional de Disruptores Endocrinos. Granada, Spain, 12-14 June.

Bronstein L. and Kovacs P.J. (2013). Writing a mixed methods report in social work research. Res. Social Work Prac. 23(3), 354-360.

DOI: $10.1177 / 1049731512471564$ 
Bulka C., Nastoupil L.J., McClellan W., Ambinder A., Phillips A., Ward K., Bayakly A.R., Switchenko J.M., Waller L. and Flowers C.R. (2013). Residence proximity to benzene release sites is associated with increased incidence of non-Hodgkin lymphoma. Cancer 119 (18), 3309-3317. DOI: 10.1002/cncr.28083

Capelli L., Sironi S., Del Rosso R., Centola P. and Il Grande M. (2007). Odour impact assessment of a MSW landfill: integrated analytical, sensorial and senso-instrumental approach. Proceedings. Eleventh International Waste Management and Landfill Symposium. Cagliari, Italy, 1-5 October. [Electronic].

CNDH (2017). Recomendación No. 10/2017 sobre la violación a los derechos humanos a un medio ambiente sano, saneamiento del agua y acceso a la información, en relación con la contaminación de los ríos Atoyac, Xochiac y sus afluentes; en agravio de quienes habitan y transitan en los municipios de San Martín Texmelucan y Huejotzingo, en el estado de Puebla; y en los municipios de Tepetitla de Lardizábal, Nativitas e Ixtacuixtla de Mariano Matamoros, en el estado de Tlaxcala. Recomendación. Comisión Nacional de los Derechos Humanos, Mexico City, Mexico, 217 pp.

CONAPO (2010). Índice de marginación por localidad 2010. Consejo Nacional de Población [online]. http:// www.conapo.gob.mx/es/CONAPO/Indice_de_Marginacion_por_Localidad_2010 10/03/2016

CONAPO (2015) Proyecciones de la población 20102015. Consejo Nacional de Población [online]. https:// datos.gob.mx/busca/dataset/proyecciones-de-lapoblacion-de-mexico 20/02/2018

Creswell J.W. and Plano Clark V.I. (2011). Designing and conducting mixed method research. 2nd ed. Sage, Thousand Oaks, California, USA, 457 pp.

Cutchin M.P., Martin K.R., Owen S.V. and Goodwin J.S. (2008). Concern about petrochemical health risk before and after a refinery explosion. Risk Anal. 28 (3), 589601. DOI:10.1111/j.1539-6924.2008.01050.x

Day R. (2007). Place and the experience of air quality. Health Place 13 (1), 249-260.

DOI: $10.1016 /$ j.healthplace.2006.01.002

Douglas M. and Wildavsky A. (1982). Risk and culture; an essay on the selection of technological and environmental dangers. University of California Press, Berkeley, California, USA, 224 pp.

Douglas M. (1996). La aceptabilidad del riesgo según las ciencias sociales. Paidós, Barcelona, Spain, 173 pp.

Fernández-Navarro P., García-Pérez J., Ramis R., Boldo E. and López-Abente G. (2017). Industrial pollution and cancer in Spain: An important public health issue. Environ. Res. 159, 555-563.

DOI: $10.1016 /$ j.envres.2017.08.049
García-Pérez J., López-Abente G., Castelló A., GonzálezSánchez M. and Fernández-Navarro P. (2015). Cancer mortality in towns in the vicinity of installations for the production of cement, lime, plaster, and magnesium oxide. Chemosphere 128, 103-10.

DOI: 10.1016/j.chemosphere.2015.01.020

Guo Y., Liu F., Lu Y., Mao Z., Lu H., Wu Y., Chu Y., Yu L., Liu Y., Ren M., Li N., Chen X. and Xiang H. (2016). Factors affecting parent's perception on air quality-From the individual to the community level. Int. J. Environ. Res. Pub. He. 13 (5), 493.

DOI: 10.3390/ijerph13050493

INEGI (2010). Censo de población y vivienda 2010. Principales resultados por localidad (ITER). Instituto Nacional de Estadística, Geografía e Informática, Mexico [online]. http://www.inegi.org.mx/sistemas/consulta_resultados/iter2010.aspx?c=27329\&s=est 10/03/2015.

INSP (2012). Encuesta Nacional de Salud y Nutrición 2012. Instituto Nacional de Salud Pública, Secretaría de Salud, Mexico [online]. http://ensanut.insp.mx/ informes/ENSANUT2012ResultadosNacionales.pdf $10 / 06 / 2016$

Interdonato M., Bitto A., Pizzino G., Irrera N., Pallio G., Mecchio A., Cuspilici A., Minutoli L., Altavilla D. and Squadrito F. (2014). Levels of heavy metals in adolescents living in the industrialised area of Milazzo-Valle del Mela (northern Sicily). J. Environ. Public Health. 2014:326845. DOI: 10.1155/2014/326845.

Janmaimool P. and Watanabe T. (2014). Evaluating determinants of environmental risk perception for risk management in contaminated sites. Int. J. Environ. Res. Pub. He. 11 (6), 6291-6313. DOI: $10.3390 /$ ijerph110606291

Lima M.L. (2004). On the influence of risk perception on mental health: living near an incinerator. J. Environ. Psychol. 24 (1) 71-84. DOI: $10.1016 / \mathrm{S} 0272-4944(03) 00026-4$

Luria P., Perkins C. and Lyons M. (2009). Health risk perception and environmental problem: findings from ten case studies in the North West of England. Summary Report. Centre for Public Health, Liverpool John Moores University, Liverpool, UK, 36 pp.

Montero R. (2004). Estudios biológicos. In: Ambiente y derechos humanos (E. Morales Sierra, Coord.). Centro Fray Julián Garcés Derechos Humanos y Desarrollo Local, Mexico, pp. 27-59.

Montero R., Serrano L., Araujo A., Dávila V., Ponce J., Camacho R., Morales E. and Méndez A. (2006). Increased cytogenetic damage in a zone in transition from agricultural to industrial use: comprehensive analysis of the micronucleus test in peripheral blood lymphocytes. Mutagenesis 21 (5), 335-342.

DOI: 10.1093/mutage/gel040 
Morales E., Chacán R. and Méndez A. (2005). Análisis legislativo y de políticas públicas en medio ambiente y salud en la cuenca del Alto Río Atoyac. Centro Fray Julián Garcés Derechos Humanos y Desarrollo Local, Mexico, pp. 27-59.

Morse J. and Niehaus L. (2009). Mixed methods design. Principles and procedures. Left Coast Press, Walnut Creek, California, USA, 194 pp.

Mota J. (2007). Reprimen a pobladores de Santa Ana Xalmimilulco. La Jornada de Oriente, Puebla, Mexico, May 9.

Omanga E., Ulmer L., Berhane Z. and Gatari M. (2014). Industrial air pollution in rural Kenya: Community awareness, risk perception and associations between risk variables. BMC Public Health 14:377.

DOI: $10.1186 / 1471-2458-14-377$

Pidgeon N. (1998). Risk assessment, risk values and the social science programme: why we do need risk perception research. Reliab. Eng. Syst. Safe. 59 (1), 5-15. DOI: 10.1016/S0951-8320(97)00114-2

Ramos-Ribeiro R. (2014). Análisis de la percepción social de los riesgos naturales: estudio comparado en municipios de España y Brasil. Ecosistemas 23 (2), 143-146.

Renn O. (2008). Risk governance. Coping with uncertainty in a complex world. Earthscan, London, England, $455 \mathrm{pp}$.

Sandoval A.M., Pulido-Flores G., Monks S., Gordillo J.A. and Villegas E.C. (2009). Evaluación fisicoquímica, microbiológica y toxicológica de la degradación ambiental del río Atoyac, México. Interciencia 34 (12), 880-887.

SDUS (2017). Diagnóstico sistémico del río Atoyac. Secretaria de Desarrollo Urbano y Sustentabilidad del municipio de Puebla. Informe Técnico. Puebla, Puebla.
SSA (2015). Bases de datos de daños a la salud. Secretaría de Salud, Dirección General de Información en Salud [online]. http://www.dgis.salud.gob.mx/contenidos/ basesdedatos/BD_Cubos_gobmx.html 20/02/2018

SERAPAZ (2008). Criminalización de la protesta social en México. Observatorio de la conflictividad social. Servicios y Asesoría para la Paz [online]. https:// truekizta.files.wordpress.com/2012/02/final-rlagosto. pdf 10/08/2016

Slovic P., Fischhoff B. and Lichtenstein S. (2007) Facts and fears: understanding perceived risk. In: The perception of risk. (P. Slovic, Ed.). Earthscan, London, England, pp. 137-153.

Stata (2011). Stata statistical software: release 12. Stata corp, College Station, Texas, USA.

Tanyanont W. and Vichit-vadakan N. (2012). Exposure to volatile organic compounds and health risks among residents in an area affected by a petrochemical complex in Rayong, Thailand. SE Asian J. Trop. Med. 43 (1), 202-211.

Taylor S. and Bogdan R. (1987). Introducción a los métodos cualitativos de investigación. La búsqueda de significados. Paidós, Buenos Aires, Argentina, 344 pp. Wachinger G., Renn O., Begg C. and Kuhlicke C. (2013). The risk perception paradox-implications for governance and communication of natural hazards. Risk Anal. 33 (6), 1049-1065.

DOI: $10.1111 / j .1539-6924.2012 .01942 . x$

WB (2015). Mortality rate, neonatal. The World Bank [online] https://data.worldbank.org/ 05/03/2015

Whittaker A. (1998). Talk about cancer: Environment and health in Ocean Point. Health Place 4 (4), 313-325. DOI: 10.1016/S1353-8292(98)00032-X 